\title{
Systemic Evaluation of Immunological Effect and Protective Effect of Live Attenuated Mumps Vaccine
}

\author{
Wan Feng Li \\ Changsha Medical University, Changsha, China, 410219 \\ 425680231@qq.com
}

Keywords: Mumps; Live attenuated vaccine; Immunological effect

\begin{abstract}
To explore the application effect of live attenuated vaccine in preventing mumps. 224 children vaccinated with live attenuated vaccine in our hospital from April 2015 to 2016 were selected as the objects of study. Live attenuated vaccine was applied in immune prevention, and the immunological effect and protective effect were evaluated and compared with 200 children that had not been vaccinated. The positive immune detection rate in vaccinated patients was relatively higher than that before (95.54\%>66.51\%). The immune success rate was $64.73 \%$; of them, immune success rate in patients with the mumps antibody titer measured value of 1:2-1:6 was as high as $100 \%$. The mumps infection rate $(0.89 \%<7.5 \%)$ and complication incidence $(0<1.5 \%)$ in vaccinated children were remarkably lower than those in non-vaccinated inspected children, with the differences being of statistical significance $(\mathrm{P}<0.05)$. The live attenuated vaccine shows outstanding superiority during mumps prevention. The risk of disease incidence can be effectively reduced after taking full advantage of its immune protection.
\end{abstract}

\section{Introduction}

The incidence of mumps is related to viral infection, which is characterized by infectivity and immunity. Mumps is relatively mild in severity; however, it can not be ignored, especially in infants and adolescent patients. Mumps may involve organs and tissues such as pancreas, gonad and central nervous system as disease progresses, which has affected their growth and development. Therefore, it is necessary to prevent mumps through inoculation, which has effective protective effect [1]. In this research, 224 patients inoculated with live attenuated vaccine in our hospital from April 2015 to 2016 were treated as the objects of study, so as to discuss its preventive effect on mumps. The details were reported as follows.

\section{Materials and methods}

\section{General information}

224 children inoculated with live attenuated vaccine in our hospital from April 2015 to 2016 were treated as the objects of study, including 130 male and 94 female cases. The age of patients ranged from 3 to 9 years, with the average of $(5.2 \pm 1.4)$ years.

\section{Methods}

\section{Inoculation method}

The live attenuated mumps vaccine (Puxianglishi, Glaxosmithkline Biological Co., Ltd, Shanghai, SFDA approval number (J20100053), which contained attenuated RIT4385 mumps virus of $\geq 103.7$ TCID50, was used for subcutaneous injection at a dose of $0.5 \mathrm{ml}$.

\section{Detection method}

Fasting venous blood samples were collected from the 224 children before and after inoculation. The blood samples were centrifuged, and the serum was separated for cryopreservation $\left(-20^{\circ} \mathrm{C}\right)$. Subsequently, mumps antibody titers in the subjects were determined using cell neutralization test. 
Moreover, the property of mumps component serum antibody was determined based on the detection results.

\section{Evaluation indexes}

Firstly, positive mumps component serum antibody: mumps antibody titer of $\geq 1 / 2$; immune success: negative mumps component serum antibody before inoculation, which transformed into positive after inoculation. Alternatively, positive mumps component serum antibody before and after inoculation, and post-inoculation antibody: pre-inoculation antibody $\geq 4$, were also deemed as immune success.

\section{Statistical processing}

Data were processed and analyzed using the SPSS19.0 statistical software. Measurement and enumeration data were expressed as ( $\left.{ }^{X} \pm s\right)$ and (\%), respectively, which were tested using t-test and chi-square test. Difference of $\mathrm{P}<0.05$ suggested statistically significant difference.

\section{Results}

\section{Immune detection results in patients before and after inoculation}

Immune detection results in patients before and after inoculation suggested that the positive mumps component serum antibody rate before inoculation was $66.51 \%$, which had elevated to 95.54\% after inoculation. The geometric mean titer (GMT) of mumps antibody before inoculation was (1: 7.24 \pm 3.32 ), which was (1: 25.54 \pm 3.75$)$ after inoculation, with the difference being statistically significant $(\mathrm{P}<0.05)$. The details were shown in Table 1.

Table 1. Immune detection results in patients before and after inoculation

\begin{tabular}{ccll}
\hline Group & & Positive & GMT \pm S \\
\hline $\begin{array}{c}\text { Before } \\
(\mathrm{n}=224) \\
\text { After } \\
(\mathrm{n}=224)\end{array}$ & inoculation & $149(66.51)$ & $1: 7.24 \pm 3.32$ \\
P-value & & $214(95.54)$ & $1: 25.54 \pm 3.75$ \\
\hline
\end{tabular}

\section{Immune success rate in patients before and after inoculation}

143 subjects had positive mumps component serum antibody before inoculation, which had accounted for $63.84 \% .81$ had negative mumps component serum antibody, taking up 36.16\%. 74 and 71 cases had positive transformation of mumps component serum antibody and 4-fold increase after inoculation, respectively. The immune success rates were $51.75 \%$ and $86.21 \%$, respectively, wile the overall immune success rate was $64.73 \%$. The details were shown in Table 2.

Table 2. Immune success rates before and after inoculation

\begin{tabular}{cccc}
\hline $\begin{array}{c}\text { Pre-inoculati } \\
\text { on antibody }\end{array}$ & $\begin{array}{c}\text { Pre-inoculation } \\
\text { GMT } \pm S\end{array}$ & $\begin{array}{c}\text { Post-inoculation } \\
\text { GMT } \pm S\end{array}$ & $\begin{array}{c}\text { Immune } \\
\text { success rate }\end{array}$ \\
\hline $\begin{array}{c}\text { Positive } \\
(\mathrm{n}=143)\end{array}$ & $1: 20.05 \pm 3.64$ & $1: 51.73 \pm 6.15$ & $74(51.75)$ \\
$\begin{array}{c}\text { Negative } \\
(\mathrm{n}=81)\end{array}$ & $1: 1$ & $1: 6.52 \pm 3.62$ & $71(87.65)$ \\
P-value & $<0.05$ & & \\
\hline
\end{tabular}

\section{Immune success rate in patients with various mumps antibody titers}

32 patients had the mumps antibody titer measured value of 1:2-1:6 before inoculation, while 113 had that of $\geq 1: 8$. The immune success rates in patients with different mumps antibody titers after inoculation were $100 \%$ (32/32) and 40.71\% (46/113), respectively. The details were shown in Table 3. 
Table 3. Immune success rates in patients with various mumps antibody titers

\begin{tabular}{cccc}
\hline $\begin{array}{c}\text { Pre-inoculation } \\
\text { mumps antibody titer }\end{array}$ & $\begin{array}{c}\text { Pre-inoculati } \\
\text { on cases }\end{array}$ & $\begin{array}{c}\text { Immune } \\
\text { cases }\end{array}$ & $\begin{array}{c}\text { success } \\
\text { Immune } \\
\text { success rate }\end{array}$ \\
\hline $1: 2 \sim 1: 6$ & 32 & 32 & 100.00 \\
$\geqslant 1: 8$ & 113 & 46 & 40.71 \\
P-value & & & $<0.05$ \\
\hline
\end{tabular}

Incidence of mumps after inoculation

Table 4. Morbidity of mumps after inoculation

\begin{tabular}{lll}
\hline Group & Mumps & Complication \\
\hline Inoculated $(\mathrm{n}=224)$ & $2(0.89)$ & 0 \\
$\begin{array}{l}\text { Non-inoculated } \\
(\mathrm{n}=200)\end{array}$ & $15(7.5)$ & $3(1.5)$ \\
P-value & $<0.05$ & \\
\hline
\end{tabular}

\section{Discussion}

Mumps is an acute respiratory infectious disease, which is more commonly seen in infants and adolescents. Patients may have unilateral or bilateral sub-earlobe swelling, accompanying with pain and fever. The incidence of mumps will cause certain damage to the pancreas, gonad and central nervous system of the children, which has negative effect on their growth and development. Therefore, positive and effective measures should be taken to prevent mumps. Inoculation is an effective method to prevent mumps, which shows immune protective effect through inducing immune response. It can effectively promote positive transformation of serum antibody or enhance positive antibody increase. Meanwhile, it can effectively control and prevent disease. Importantly, its durability allows for long-term and continuous guaranteeing human physical health [2].

To sum up, the application of live attenuated vaccine has favorable immunological effect and protective effect on preventing mumps. It can better protect physical health of children and promote their growth and development.

\section{References}

[1] Yan X, Wang D, Liang F, et al. Recombinant HPV16L1-attenuated Shigella live vector vaccine induced strong vaginal and systemic immune responses in guinea pigs model[J]. Human Vaccines \& Immunotherapeutics, 2014, 10(12):e36084.

[2] Jamil R K, Taqavian M, Sadigh Z A, et al. Evaluation of the thermal stability of a novel strain of live-attenuated mumps vaccine (RS-12 strain) lyophilized in different stabilizers[J]. Journal of Virological Methods, 2014, 199(4):35-38. 